University of Nebraska - Lincoln

DigitalCommons@University of Nebraska - Lincoln

Biological Systems Engineering: Papers and

Publications

Biological Systems Engineering

2009

\title{
Indirect Land Use Emissions in the Life Cycle of Biofuels: Regulations vs. Science
}

Adam J. Liska

University of Nebraska-Lincoln, aliska2@unl.edu

Richard K. Perrin

University of Nebraska-Lincoln, rperrin@unl.edu

Follow this and additional works at: https://digitalcommons.unl.edu/biosysengfacpub

Part of the Biological Engineering Commons

Liska, Adam J. and Perrin, Richard K., "Indirect Land Use Emissions in the Life Cycle of Biofuels: Regulations vs. Science" (2009). Biological Systems Engineering: Papers and Publications. 144. https://digitalcommons.unl.edu/biosysengfacpub/144

This Article is brought to you for free and open access by the Biological Systems Engineering at DigitalCommons@University of Nebraska - Lincoln. It has been accepted for inclusion in Biological Systems Engineering: Papers and Publications by an authorized administrator of DigitalCommons@University of Nebraska Lincoln. 


\title{
Indirect Land Use Emissions in the Life Cycle of Biofuels: Regulations vs. Science
}

\author{
Adam J. Liska and Richard K. Perrin \\ University of Nebraska-Lincoln, Lincoln, NE, USA
}

\begin{abstract}
Recent legislative mandates have been enacted at state and federal levels with the purpose of reducing life cycle greenhouse gas (GHG) emissions from transportation fuels. This legislation encourages the substitution of fossil fuels with "low-carbon" fuels. The burden is put on regulatory agencies to determine the GHG-intensity of various fuels, and those agencies naturally look to science for guidance. Even though much progress has been made in determining the direct life cycle emissions from the production of biofuels, the science underpinning the estimation of potentially significant emissions from indirect land use change (ILUC) is in its infancy. As legislation requires inclusion of ILUC emissions in the biofuel life cycle, regulators are in a quandary over accurate implementation. In this article, we review these circumstances and offer some suggestions for how to proceed with the science of indirect effects and regulation in the face of uncertain science. Besides investigating indirect deforestation and grassland conversion alone, a more comprehensive assessment of the total GHG emissions implications of substituting biofuels for petroleum needs to be completed before indirect effects can be accurately determined. This review finds that indirect emissions from livestock and military security are particularly important, and deserve further research.
\end{abstract}

Keywords: biofuels, life cycle assessment, greenhouse gas emissions, land use change, deforestation, econometric models, livestock, carbon sequestration, tar sands, military

\section{Life Cycle Emissions Standards for Biofuels: Legislation}

$\mathrm{n}$ an era of declining fossil fuel reserves and increasing atmospheric carbon dioxide levels, biofuels may provide an opportunity to both reduce greenhouse gas (GHG) emissions and provide a source of domestic liquid fuel. The US Energy Independence and Security
Act (EISA) of 2007 and the Low Carbon Fuel Standard (LCFS) of California favor biofuels and other low-carbon fuels, if their life cycle GHG emissions are lower than fossil fuels. EISA specifies that indirect as well as direct emissions are to be included in the life cycle assessment (LCA) of biofuel emissions, which is appropriate if the objective of the legislation is to reduce GHG emissions. It has been recently estimated, however, that 
indirect land use change (ILUC) associated with biofuels releases GHG emissions well in excess of gasoline emissions. ${ }^{1}$ But there is much scientific uncertainty in measuring indirect emissions related to both biofuels and gasoline, thus presenting regulators with a dilemma of whether and how to calculate them.

For biorefineries built since 2007 to qualify as lowcarbon fuel producers, EISA legislation requires that they reduce life cycle GHG emissions relative to gasoline by specific fractions: $20 \%$ for corn-ethanol, $60 \%$ for cellulosic ethanol, and $50 \%$ for other advanced biofuels. EISA defines life cycle GHG emissions as:

the aggregate quantity of GHG emissions (including direct emissions and significant indirect emissions such as significant emissions from land use changes), as determined by the Administrator, related to the full fuel lifecycle, including all stages of fuel and feedstock production and distribution, from feedstock generation or extraction through the distribution and delivery and use of the finished fuel to the ultimate consumer... ${ }^{2}$

California's LCFS similarly requires that the emissions of biofuels be measured relative to the petroleum fuels they replace, but it does not exempt existing biofuel producers. In addition, multistate regional climate compacts that are exploring climate policies and capand-trade markets will likely adopt similar low-carbon fuel standards in accordance with California regulations. Although regulators are rapidly pushing ahead, the underpinning science for estimating indirectly caused emissions due to biofuel production is currently in its infancy. ${ }^{3}$

In setting regulatory standards in the presence of scientific uncertainty, regulators run the risk of establishing inefficient or counter-productive rules. It seems clear that the environmentally determined social cost of overestimating emissions from biofuel production is lower than the cost of underestimating, for the following reasons. If the estimate is higher than the true but unknown level of emissions, the development of the biofuel will be too slow, and the cost to society is the foregone GHG benefits during the interim until the true emissions footprint is established. On the other hand, if the initial estimate is lower than the true emissions, one cost to society is greater climate-mediated GHG damage than anticipated during the interim until the true footprint is established. In addition to this cost, we must add the poten- tially wasted investment of excess biofuel development and infrastructure relative to that which would have been appropriate to the true GHG emissions intensity.

Should regulatory policies encourage development of biofuels in the presence of scientific uncertainty of this nature? A general precautionary principle has been embraced by many, asserting that scientific uncertainty should not be a reason for delaying action to prevent harm. ${ }^{4}$ Here, scientific uncertainty may be a legitimate reason for delaying action to encourage biofuel development. If it were equally likely that a biofuel is harmful or beneficial for climate change, delay would be desirable because of the potential that infrastructure may be a wasted investment if subsequent evidence comes down on the side of GHG harm. In comparing biofuels with petroleum, regulators must somehow incorporate both fairly accurate scientific knowledge about direct life cycle emissions, and relatively diffuse and uncertain scientific knowledge concerning potentially significant indirect emissions, so as to achieve such a precautionary comparison.

The contribution and obligation of science with respect to these issues is to estimate as precisely as possible the change in GHG emissions resulting from the substitution of a given biofuel for gasoline. To do this, it is necessary to estimate both direct and indirect emissions for both biofuels and gasoline, especially when indirect effects are potentially large. Only with this information in hand can climate policy and associated regulations be designed to reduce emissions most efficiently and effectively.

\section{Life Cycle Emissions from Biofuels: Industrial Ecology}

LCA is a method in the field of industrial ecology to gauge the full range of environmental impacts from a specific industrial system. Industrial ecology is a science concerned with the links between industrial and natural systems that "provides a theoretical basis and an objective understanding upon which reasoned improvement of current practices can be based." ${ }^{5}$ LCA has been used to voluntarily certify industrial systems to ensure that they do not exceed specified environmental thresholds. LCA has not, however, been previously used in regulations by the US Environmental Protection Agency (EPA), and the application of LCA to biofuels is the first attempt by the EPA to formally apply the method to regulated entities. 
The science of LCA has been widely used to assess the net energy efficiency and GHG emissions intensity for a range of biofuels. ${ }^{6}$ LCA oft en uses mathematical models of unique industrial systems to analyze their environmental impacts. For emissions regulations, models can be used to generate an emissions inventory of the production life cycle and provide a transparent accounting of the total GHG intensity for the biofuel system. When models are used in the regulatory process, it is critical that model parameters are adequately integrated with empirical measurements of the evaluated systems. $^{7}$

The direct LCA of corn-ethanol emissions was recently reassessed based on new statistics from the rapidly expanding industry. ${ }^{8}$ Natural gas powered dry mills, the largest industry sector, were found to reduce life cycle GHG emissions compared to gasoline by $51 \%$ on average. Compared to previous studies, this unexpected result reiterates the need for better integration between measurements and models to more accurately define the direct GHG emissions intensity of fuels. ${ }^{7}$ Following previous LCA's, ${ }^{6,9}$ the conventional boundaries of the biofuel life cycle were used, and therefore did not include GHG emissions from ILUC. ${ }^{8}$ Because recent analysis has shown that GHG emissions from ILUC could be significant when included in the biofuel life cycle ${ }^{1}$ and the goal of the legislation is to reduce cumulative emissions, it is clear that the boundaries of LCA analysis should be extended to include them. ${ }^{3,10}$

There is precedent in industrial ecology theory to consider the more distant indirect effects of industrial systems. Robert Socolow has described industrial ecology as "'subversive' in that it treats with indifference both what it is easy to regulate and what is hard to regulate, arguing that the willingness to look at environmental problems with fresh eyes has the power to generate new insights." 11

LCA is also a method that is concerned with a holistic picture of industrial systems that seeks to solve one environmental problem (such as GHG emissions) by avoiding the creation of new indirect problems in the process (such as ILUC). ${ }^{12}$ Furthermore, it has been noted that "policymakers cannot afford the luxury of ignoring the many impacts of their actions, for it is the summed impacts, intended and unintended, that determine whether a regulatory intervention has advanced, or even retarded, the approach toward sustainability." 5

\section{Biofuels and Land Use GHG Emissions}

Historically, global land use change (LUC) has been a large source of carbon emissions, contributing one third of anthropogenic GHG emissions since 1750, and one-fifth of emissions during the 1990s. ${ }^{13,}{ }^{14}$ If current deforestation rates continue, the extent of the Amazon rainforest is projected to decrease by $40 \%$ by 2050 , releasing 32 billion metric tons of carbon $(\mathrm{PgC})$ to the atmosphere (Figure 1). ${ }^{15}$ In conjunction with human activities, climate change processes could further accelerate loss and lead to a 55\% reduction of the Amazon rainforest over the next 20 years. ${ }^{16}$ Without appropriate policies and economic incentives, up to $130 \mathrm{Pg}$ of terrestrial carbon could be emitted globally due to LUC by $2100 .{ }^{17}$

A general understanding of the exact causes of LUC, however, is lacking due to the complexity of immediate drivers and distant social influences. ${ }^{18,} 19$ Tropical deforestation has been shown to be influenced by up to 16 direct causes associated with agricultural expansion, wood extraction, and infrastructure development. ${ }^{19,} 20$ These direct causes work in conjunction with at least 17 underlying causes associated with demography, economics, technology, government policies, and cultural attitudes. In most individual cases of tropical LUC, three to four underlying causes drive two to three direct causes - although the most common indirect and direct causes are economics and agricultural expansion, respectively. ${ }^{20}$ For the Amazon, soybean expansion in Brazil has largely been driven by demand from Europe and China. ${ }^{21}$

Direct LUC from biofuels occurs when changing from the previous land cover to the biofuel crop itself. For example, this happens where rainforest is cut down to plant oil palm for biodiesel or where conservation lands are tilled for row crops and other biofuels. ${ }^{22-26}$ Measurement of emissions due to direct LUC has been less controversial than those from ILUC, simply because the complexities of human responses through markets and institutions are generally not involved.

The logic that supports the ILUC hypothesis is that biofuel production competes for agricultural resources, this competition results in an increase in prices of agricultural products, and these price increases cause additional conversions of the world's grasslands and forests to cropland (Figure 1). 1, 3, 27, 28 This additional land conversion results in loss of carbon previously sequestered 
in grassland and forest ecosystems. These emissions are an indirect result of producing biofuels, and if significant, they should be considered in calculating the GHG implication of adopting biofuels. The logic of ILUC emissions is clear, but the significance is not, and measurement is highly problematic given the complexities of the economic and social systems that connect biofuel production in the USA with land conversion throughout the world. Empirical verification of ILUC due to recent expansion of the biofuel industry is problematic because those expansions constitute a very small driver relative to global LUC, so the biofuel impact is likely to be swamped by other causes. Therefore, ILUC must be evaluated with some type of modeling approach, although it is possible that case studies could offer some evidence useful in evaluating ILUC.

The first published study of global ILUC from US ethanol production by Searchinger et al. ${ }^{1}$ estimated that over a ten-year period, allocation of 12.8 Mha of corn to produce ethanol in the USA would result in 10.8 Mha of new cropland around the world. The conversion of native ecosystems to cropland would result in $3.8 \mathrm{Pg}$ of $\mathrm{CO}_{2}$ equivalent $\left(\mathrm{CO}_{2} \mathrm{e}\right)$ emissions in total over 30 years $\left(127 \mathrm{TgCO}_{2} \mathrm{e} \mathrm{yr}^{-1}\right)$ (Table 1). This emissions estimate due to ILUC alone added $104 \mathrm{gCO}_{2} \mathrm{e} \mathrm{MJ}^{-1}$ attributable to ethanol, higher than estimated emissions from the gasoline it would replace. Clearly this is a significant amount, and if correct it eliminates any climate change benefits attributable to corn-ethanol. However, this is only one study of ILUC, subject to many uncertainties and alternative procedures. The Searchinger study utilized a partial equilibrium model of world agricultural prices and land allocation. The model projected land allocations under two different petroleum price scenarios, which resulted in US ethanol production levels of 56 and 112 billion liters per year (bly). All other policy and economic conditions were held constant to isolate the effect of US ethanol production on global LUC. The estimated annual marginal increase in global cultivated area due to increased ethanol was about 1.1 Mha $\mathrm{yr}^{-1}$, compared with recent increases of about 4.3 Mha $\mathrm{yr}^{-1}$ during 19962005, or compared to forest losses of about 7.2 ${\mathrm{Mha} \mathrm{yr}^{-1}}^{-1}$ (FAOSTAT) ${ }^{63}$

The ILUC estimates by Searchinger et al. are not implausible, though they are subject to many uncertainties. A previous study by Delucchi ${ }^{29}$ estimated that adding ILUC emissions from within the USA to the cumulative emissions intensity of corn-ethanol would increase its GHG intensity by $26 \%$, whereas the ILUC effect from

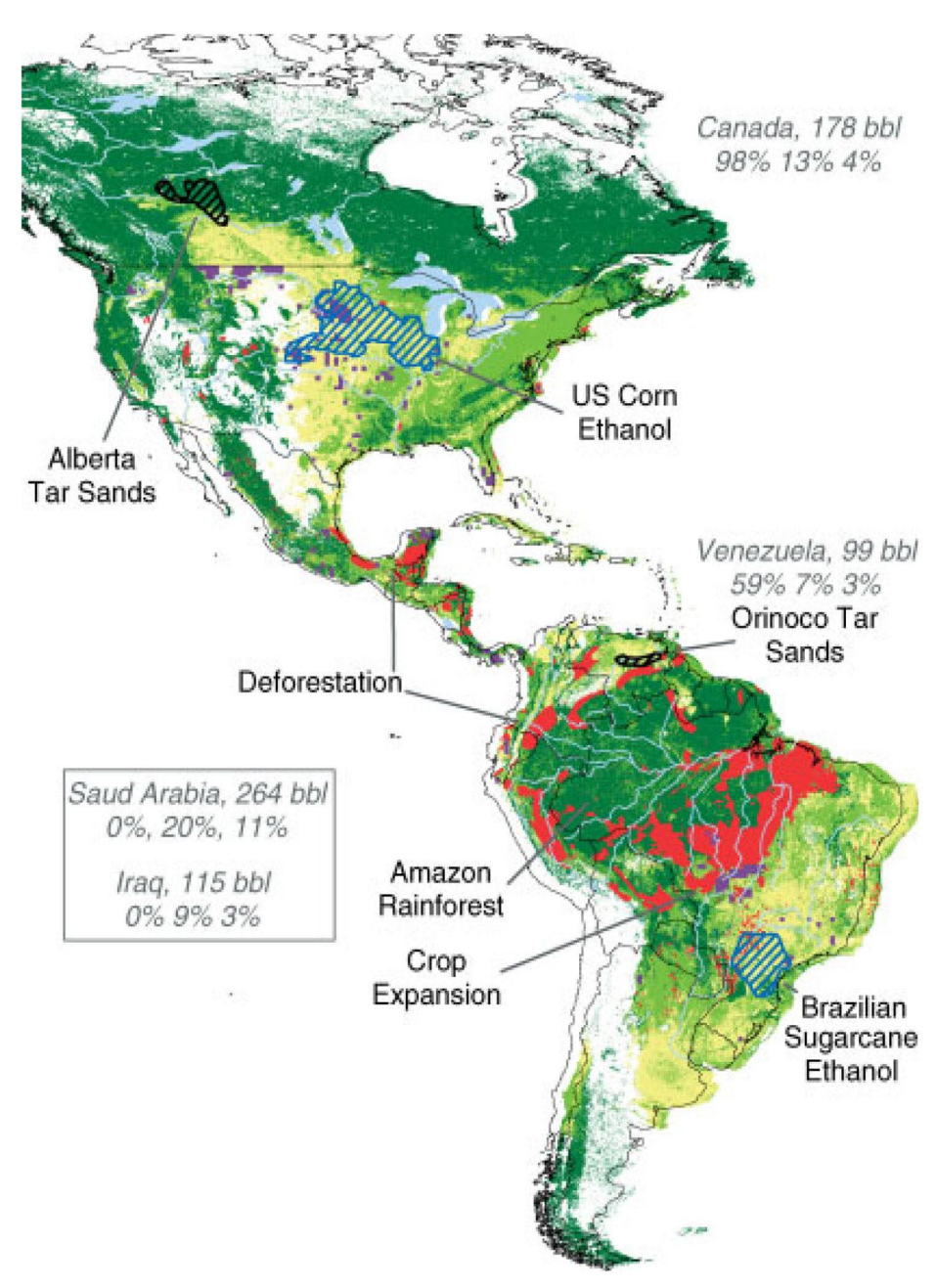

Figure I. Competition between agriculture and forest reserves in the western hemisphere, and emerging biofuel and fossil fuel resources. Cropping systems (yellow, $>30 \%$ of area;), forests (green, $>40 \%$ coverage), and overlap (light green). Deforestation (red) from 1980-2000 and crop expansion (purple) from 1980-1990.14 Country labels: petroleum reserves in 2009 in billion barrels (bbl), and percentages: reserves as tar sands, 2009 global reserves, and 2007 global production, respectively. ${ }^{57,58}$ Biofuels only comprise a portion of the designated areas. This stylized map was constructed with GIS data from the Millennium Ecosystem Assessment, http://www.millenniumassessment.org [January 2009]). 
Table I. Additional factors and uncertainties that determine net changes in indirect greenhouse gas emissions from transportation fuel production. Emissions units in $\mathrm{TgCO}_{2} \mathrm{e} \mathrm{yr}^{-1}$.

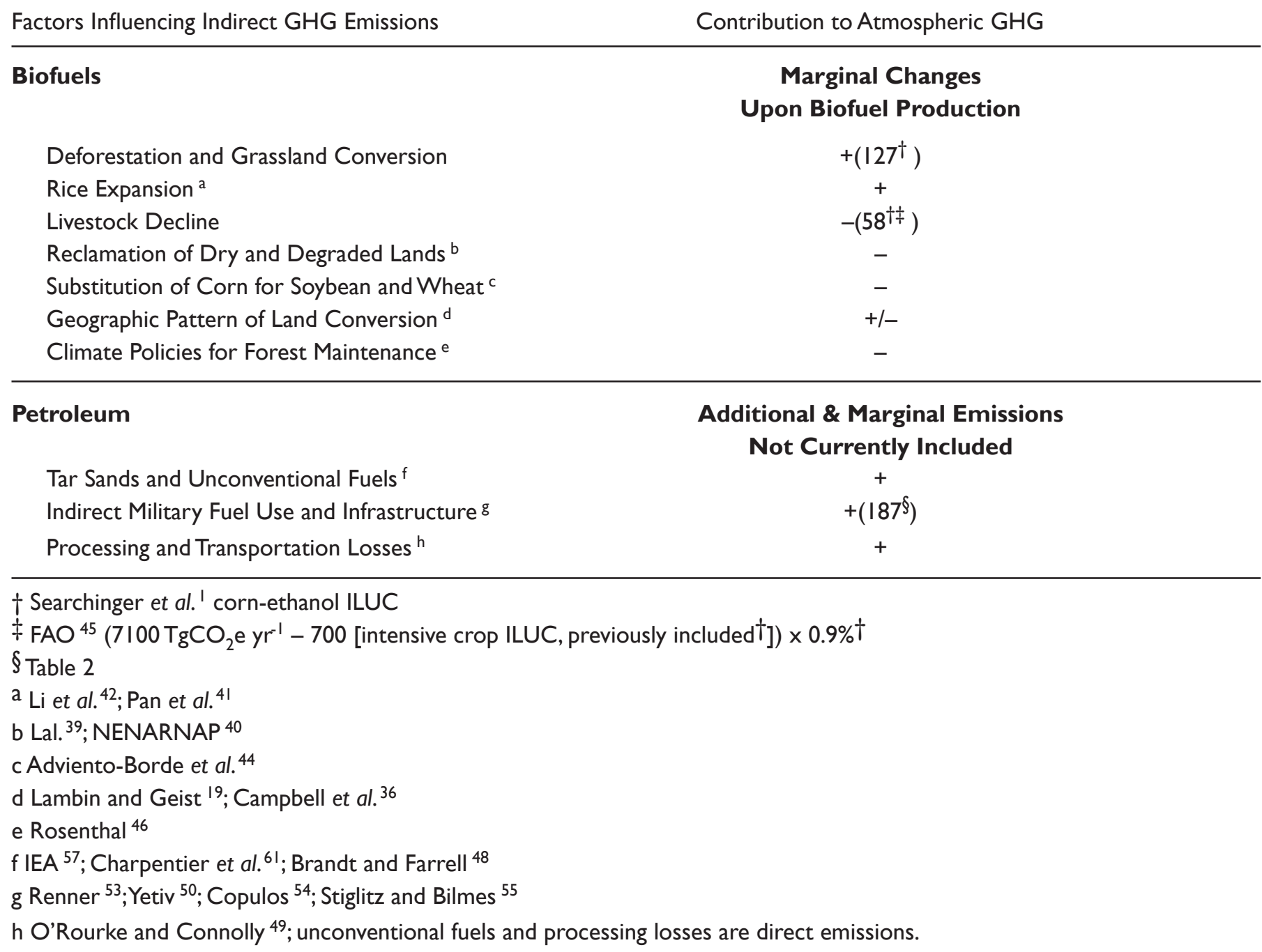

only US LUC that is attributable to ethanol calculated by Searchinger et al. is $32 \%$. A more recent study using GTAP, a computable general equilibrium model, implied that 57 bly of additional corn-ethanol would result in a global increase of 10.5 Mha of additional cropland, ${ }^{30}$ remarkably similar to the Searchinger et al. estimate of 10.8 Mha. Numerous other modeling studies are underway, but results are not yet reported. ${ }^{31}$

Attempts to validate ILUC from observed changes in land use offer inconclusive results. Brazilian Amazon deforestation from soybean expansion in Mato Grasso, for example, was recently reported to be directly correlated (correlation coefficient of 0.72) with soybean price during 2001-2004. ${ }^{32}$ This result is consistent with the ILUC hypothesis, though it occurred during a time prior to rapid biofuel expansion. ${ }^{33}$ But the rate of Brazilian Amazon deforestation peaked in 2004, and has fallen since then, yielding a negative correlation of -0.53 with soybean price during the four years since $2004 .{ }^{34}$ While this may appear contrary to the ILUC hypothesis, deforestation may have fallen faster without biofuels.

\section{Uncertainties and Indirect Emissions Savings from Biofuels}

Accurate accounting of indirect emissions from biofuels, however, will need to be more comprehensive than investigating marginal deforestation and grassland con- 
version alone. All significant indirect changes that influence the global carbon cycle and net GHG emissions need consideration. To illustrate the overall uncertainty in land emissions, estimates of the size of the terrestrial carbon source emitted to the atmosphere have the largest uncertainty in the global carbon cycle, and the net global land-atmosphere carbon flux is primarily estimated from measurements in two other carbon pools: the atmosphere and ocean. ${ }^{13}$

Economic modeling of ILUC due to biofuels entails uncertainties at every stage: the effect of biofuel demand on world prices of all agricultural commodities, the responsiveness of crop yields and consumption patterns to these price increases, and responsiveness of land conversion to the price increases in specific ecological regions of the world. The Searchinger model contained no specific land supply structure for various countries, and models with plausible land conversion supply curves appropriate for each country have not yet been published. ${ }^{3,} 35$ The geographic pattern of expansion from such models may be critical, because agricultural expansion can occur on the 385-472 Mha of abandoned agricultural land as opposed to forested areas. ${ }^{36}$ In common with research on general LUC, ${ }_{1}^{19}$ validation of these models will be difficult, given the limitations imposed by the limited number of years that biofuels have influenced the market and the confounding impacts of petroleum price shocks, fast income growth in some areas of the world, and global economic recession.

Commodity price increases from biofuels may also have beneficial ILUC by providing additional incentive to restore degraded soils, which will result in soil carbon sequestration ${ }^{37}$ and slow the spread of desertification. Drylands cover $41 \%$ of global land, and $10-20 \%$ of this area is degraded.$^{38}$ Restoration of drylands could sequester up to 0.9 to $1.9 \mathrm{PgC} \mathrm{yr}^{-1}$ in soil from the atmosphere. ${ }^{39}$ Degraded soils in China are planned to be reclaimed with a biofuel program to produce 4.8 bly of ethanol from sweet sorghum. ${ }^{33}$ Furthermore, land reclamation is also reported in Egypt in efforts to expand and restore cropland due to rising commodity prices (Table 1). ${ }^{40}$

Increased rice production in the tropics is a potential source of increased GHG emissions due to biofuelinduced grain price increases, not considered in the Searchinger et al. study. Pan et al. ${ }^{41}$ estimate that Chinese

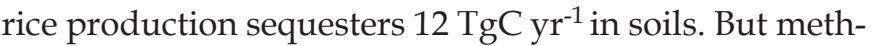
ane emissions from paddy rice in China ${ }^{42}$ of $\sim 8 \mathrm{TgCH}_{4}$ $\mathrm{yr}^{-1}$ would more than offset that soil carbon sequestration, given that methane has a 100 -year global warming potential 25 times $\mathrm{CO}_{2} \cdot{ }^{13}$ Also in the tropics, it has been recently proposed that producing biofuels from oil palm plantations established on degraded grasslands rather than from conversion of tropical rainforests and peat lands would result in net carbon sequestration in less than 10 years. ${ }^{43}$ Additionally, grain crop substitutions, such as wheat and soybean declines with increases in corn area, could also increase net soil carbon sequestration due to relatively greater biomass and residue production. ${ }^{1,44}$

Perhaps the largest indirect emissions savings from biofuel production is reduced livestock numbers due to higher feed prices. Livestock have an immense GHG footprint, accounting for nearly $80 \%$ of agricultural emissions and $\sim 18 \%$ of global anthropogenic GHG emissions $\left(7.1 \quad \mathrm{PgCO}_{2} \mathrm{e} \mathrm{yr}^{-1}\right)$-more than the entire global transportation system. ${ }^{45}$ Searchinger et al. ${ }^{1}$ (Table B1) estimate that livestock production would fall by $0.9 \%$ as a result of an additional 56 bly of cornethanol production, and their model accounts for associated reductions in cropland used for feed grains. But the model does not account for other changes in livestock-related emissions including less methane emissions from enteric fermentation and manure, and reduction in livestock-related deforestation, which account for $\sim 6.4 \mathrm{PgCO}_{2} \mathrm{e} \mathrm{yr}^{-1}$ globally. A $0.9 \%$ decrease in livestock could contribute an additional emissions reduction of about $58 \mathrm{TgCO}_{2} \mathrm{e} \mathrm{yr}^{-1}$, which would offset nearly one half of Searchinger's ILUC estimate of 127 $\mathrm{TgCO}_{2} \mathrm{e} \mathrm{yr}^{-1}$ (Table 1).

Potentially influencing LUC rates and the results of ILUC calculations, the United Nations is considering paying developing countries to prevent deforestation in the climate treaty to succeed Kyoto. ${ }^{46}$ It has been estimated that Amazon deforestation could be halted in 10 years for $\$ 8$ billion from carbon markets $(<\$ 2$ per $\mathrm{MgC}) .{ }^{16}$ Such forces could quickly change deforestation trends and limit the impacts of indirect price effects on biofuel emissions.

All of the above considerations suggest that current ILUC models likely estimate cumulative indirect GHG emissions dynamics with significant inaccuracy (Table 1). Further research is clearly needed to improve our understanding of ILUC emissions from biofuels before we can be reasonably sure of biofuels net effects relative to direct and indirect GHG emissions of petroleum fuels. 


\section{GHG Emissions Intensity of the Petroleum Baseline: Uncertainties and Trends}

Comparisons between biofuels and fossil fuels will also require a more thorough assessment of the life cycle GHG emissions from petroleum. Besides combustion emissions, life cycle emissions estimates for gasoline generally include upstream emissions in gasoline production primarily from crude oil recovery, refinery emissions, and flaring losses. ${ }^{47,} 48$ Excluded are emissions due to military security associated with the acquisition of Middle Eastern petroleum, changes in the composition of petroleum supplies toward more GHGintensive fuels, and other additional emissions from petroleum extraction, refining, and transportation. ${ }^{49}$

It is clear that a portion of US military expenditures and associated GHG emissions are related to the protection of oil exports from the Middle East. Here we make some preliminary calculations of the size of these emissions. Whether substitution of biofuels for petroleum would result in a reduction of those emissions, and if so by how much, is an open question for study and debate, but our calculations show that the potential is significant.

Since 1979, there has been a strategic buildup of the US military in the Middle East for protection of exported oil..$^{50}$ In addition to GHG emissions from military fuel use, emissions also derive from materials for military buildings, vehicles, and munitions. ${ }^{51,52}$ In 1997, it was estimated that the US military used $5-15 \%$ of all US materials consumed (e.g., steel and aluminum), but used up to $40 \%$ of other more GHG-intense metals such as titanium, ${ }^{52}$ resulting in total military emissions at up to $10 \%$ of all US emissions. ${ }^{53}$ To our knowledge, more recent estimates of military-related emissions are not available, but expenditures provide a starting point to estimate their current magnitude. Estimated expenditures related to Middle East oil security alone range from $\$ 138$ billion annually ${ }^{54}$ (out of the $\$ 526$ billion spent on US defense in 2007, not including Iraq and Afghanistan operations) to $\$ 3$ trillion for the Iraq war. ${ }^{55}$ Whether Iraq operations were ultimately due to oil or national security is debated, but oil appears to be a dominant factor ${ }^{55}$; even US involvement in Afghanistan has strong links to accessing oil reserves in Central Asia. ${ }^{56}$ If $10 \%$ of total US GHG emissions were due to the military, and if only $26 \%$ of those operations were for protection of oil supplies (assuming no expenditures for the Iraq war), total indirect military emis-

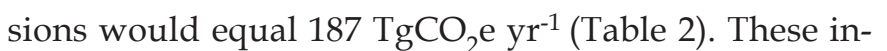
direct military emissions would add $98 \mathrm{gCO}_{2} \mathrm{e} \mathrm{MJ}^{-1}$ to gasoline produced from Middle Eastern petroleum and raise the GHG intensity of gasoline from this source by roughly two-fold.

It is important that research efforts focus on estimating the portion of the total GHG emissions of the US military that might be reduced if US petroleum imports are reduced via use of biofuels. Corn-ethanol could not substitute for more than an additional 3-4\% of imports, but all future biofuels could substitute for substantial fractions of current imports. The conceptual and measurement problems for these estimates are difficult, and attribution of the military burden to energy and economic security (e.g., oil) versus inhibiting terrorism will need to be better defined by economists, political scientists, and historians. These emissions should be estimated with greater accuracy and properly allocated when implementing regulations for the indirect effects of fuels.

The average GHG-intensity of the global petroleum supply is also becoming more intense due to depletion of easily accessible deposits. ${ }^{48}$ Global conventional crude oil production is projected to remain relatively constant over 2007-2030, as increases in new capacity are offset by declines from existing fields. ${ }^{57}$ The bulk of the increase in global oil production will come from natural gas liquids (e.g., propane) and unconventional resources and technologies, primarily tar sands. Global conventional oil reserves are estimated at 1.34 trillion barrels, ${ }^{58}$ while global economically recoverable tar sands reserves are up to 2 trillion barrels. ${ }^{57}$ Roughly $17.3 \%$ of current global petroleum reserves are in tar sands found in Canada (175 bbl, 13\%) and Venezuela (58 bbl, 4.3\%) with a total of $233 \mathrm{bbl}$, compared to 264 bbl in Saudi Arabia (which comprises 20\% of reserves, and is the largest reserve globally) (Figure 1). ${ }^{57,58} \mathrm{Tar}$ sands reserves that are ultimately economically recoverable from Canada and Venezuela are estimated to be roughly 315 and $250 \mathrm{bbl}$, respectively. ${ }^{57}$ These two countries are also the first and fourth largest exporters of petroleum to the USA, and if this dependence continues, tar sands will likely be an increasing fraction in gasoline, which could rise to nearly a fifth of supply in the next 11 years (Figure 2).

Tar sands (also called oil sands, extra-heavy oil, or bituminous sands) contain dense viscous petroleum mixed in sand and clay that requires energy-intensive extraction and processing. Production of unconven- 
Table 2. Estimated indirect greenhouse emissions from US gasoline production due to military security in the Middle East.

\section{Military GHG Emissions from Oil Security}

US total GHG emissions in 2007, ${ }^{\mathrm{TgCO}} \mathrm{Tg}_{2} \mathrm{yr}^{-1}$

Estimated emissions due to military, ${ }^{\mathrm{b}} \%$

Estimated fraction of military security for oil, ${ }^{c} \%$

Military emissions for Middle Eastern oil, $\mathrm{TgCO}_{2} \mathrm{e} \mathrm{yr}^{-1}$

\section{Oil Imports from the Middle East}

Oil imports from Persian Gulf, ${ }^{\mathrm{mb}} / \mathrm{d}$

Refining,e liters of gasoline per barrel of oil

US gasoline feedstock imports from Persian Gulf, billion liters per year

\section{Indirect Gasoline GHG Emissions due to Military Security}

Military emissions per gallon gasoline, $\mathrm{TgCO}_{2}$ e per billion liters

Military emissions for gasoline, ${ }^{\mathrm{f}} \mathrm{gCO}_{2} \mathrm{e} \mathrm{MJ}^{-1}$

Gasoline emissions intensity, Persian Gulf gasoline, ${ }^{g} \mathrm{gCO}_{2} \mathrm{e} \mathrm{MJ}{ }^{-1}$

Gasoline emissions intensity, US avg., ${ }^{\mathrm{h}} \mathrm{gCO}_{2} \mathrm{e} \mathrm{MJ}^{-1}$
7,125

26.2

187

2.2

74.2

58.6

3.19

98.0

194.9

107.1

a EPA 62

b Renner 53

c Copulos ${ }^{54}$; Stiglitz and Bilmes 55

d US Department of Energy; http://tonto.eia.doe.gov/dnav/pet/pet_move impcus_a2_nus_ep00_im0_mbblpd_a.htm (March 2009)

e US Department of Energy; http://tonto.eia.doe.gov/ask/gasoline_faqs.asp\#gallons_per_barrel (March 2009)

f Gasoline, energy density, $32.6 \mathrm{MJ} \mathrm{L}{ }^{-1}$

g Military emissions plus gasoline 47

h Persian gulf imports are $10.4 \%$ of US total fuel use, adding $10.2 \mathrm{gCO}_{2} \mathrm{e} \mathrm{MJ}^{-1}$ to US avg. gasoline emissions.

tional petroleum sources, such as tar sands, coal-toliquids, and oil shale, are generally more energy and emissions intense than the current supply of petroleum and direct emissions from most biofuels (Figure 3). As more gasoline is derived from these sources in the future, the GHG-intensity of gasoline will increase, and life cycle emissions estimates need to account for these changes.

\section{Conclusion: Incomplete Information and Policy}

Estimation and regulation of the combined impacts (including direct and indirect effects) of industrial products is an effort towards sustainability. ${ }^{5}$ Appropriate accounting of all GHG emissions related to use of both fuel types is necessary to implement life cycle emissions regulations and to inform policy-makers in the creation of an effective climate policy framework.
Bioenergy has long-term potential to be a distributed energy source that recycles atmospheric carbon. If use of bioenergy is shown to be a significant driver of LUC, ${ }^{24}$ policies are needed to reduce these indirect impacts, if bioenergy is to be encouraged. While such policies might have climate benefits, the global nature of the problem introduces difficult jurisdictional and equity issues that diminish the prospect for their timely adoption.

It seems clear that the ILUC emissions from biofuels may well be significant, but have not yet been established with a reasonable degree of certainty. This review discusses some additional factors (quantified and unquantified) that are or could be significant, and must be more accurately estimated to better quantify indirect effects. Until further studies reduce this uncertainty, it is not clear whether additional corn-ethanol capacity is beneficial or harmful for climate change compared to conventional fossil fuels. A more comprehensive assessment of the total GHG emissions implications of substituting biofuels for petroleum needs to be completed before the net GHG effect can be confidently determined 


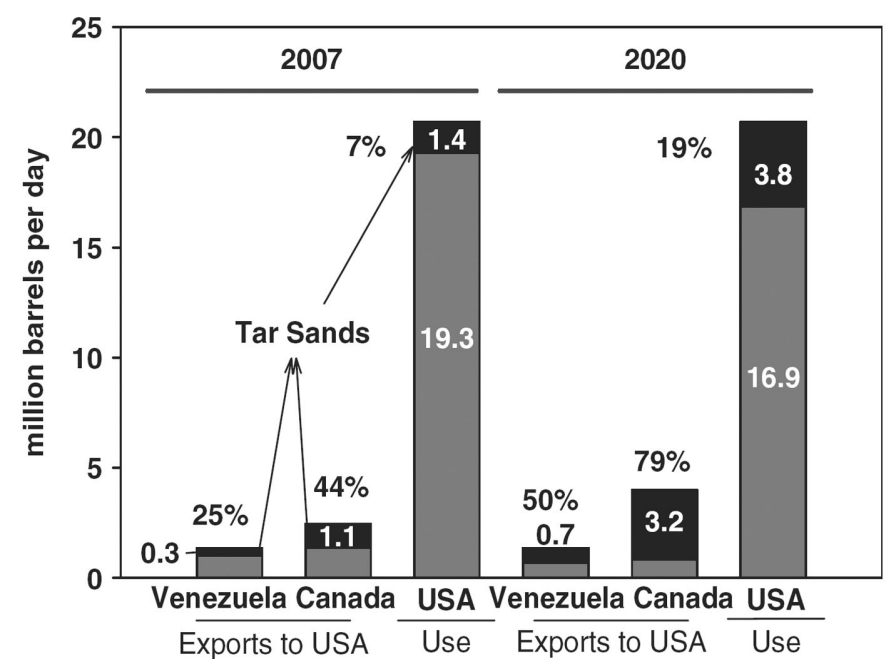

Figure 2. Current and projected USA petroleum imports and fuel supply from tar sands from Venezuela and Canada. The percentage of tar sands in total production from Canada is reported for 2007 (44\%) and estimated for 2020 (79\%). ${ }^{60}$ The fraction of tar sands in Venezuela production is estimated for 2007 and 2020 based on IEA reports (World Resources Institute, http://www.wri.org/publication/content/I0339 [February 2009]). Projections assume USA consumption and imports are constant from 2007 to 2020 (US Department of Energy), USA imports the same proportion of Canadian production (89\%) and the same rate from Venezuela $(1.36 \mathrm{mb} / \mathrm{d})$, which increases tar sands production to $50 \%$.

and regulated (Table 1). Yet, except for rice expansion, all of the additional factors considered here would result in more favorable estimates of the benefits of substituting additional biofuels for fossil fuels. We hasten to point out that the ILUC emissions and other indirect emissions from existing ethanol capacity are no longer at issue, given that whatever such emissions might be, they have already occurred. The GHG emissions from future ethanol production at those plants are limited to direct emissions, such as those measured by more conventional methods. ${ }^{8,9}$

In the context of overall national policies, biofuels may contribute to national security, ${ }^{59}$ rural development objectives, as well as climate change objectives. Thus, climate implications are not the only criterion by which the value of biofuels should be judged; support via subsidies and mandates may be desirable even if GHG benefits are negligible or uncertain. It is nonetheless important that the probable GHG impact of the substitution

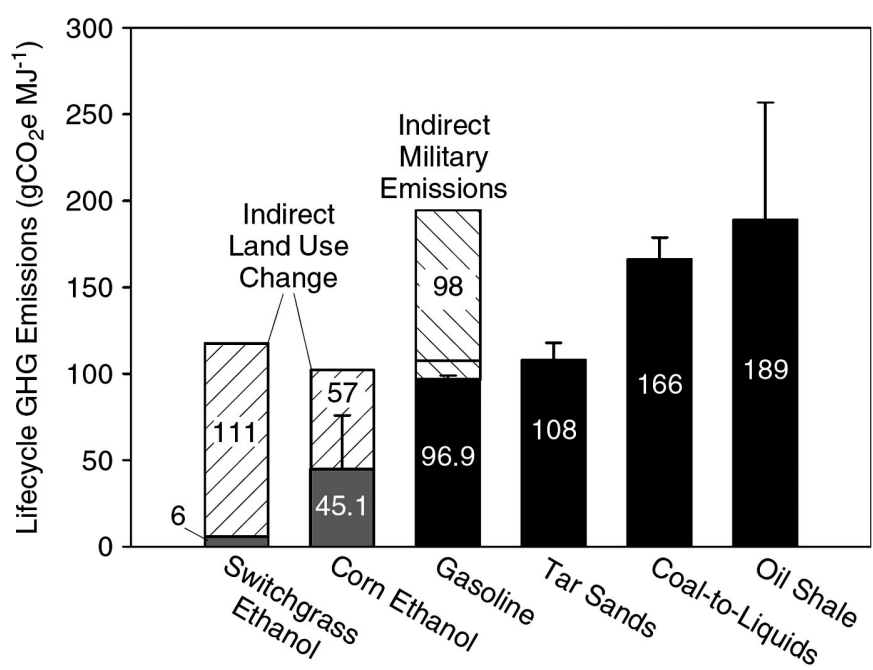

Figure 3. Greenhouse gas emissions intensity of transportation biofuels (gray bars) and fossil fuels (black bars), with inclusion of indirect land use emissions in the life cycle (hatched bars) and indirect emissions from gasoline originating in the Persian Gulf. All values are averages, and error bars indicate maximum estimates. Sources: Switchgrass cellulosic ethanol: Schmer et al. ${ }^{63}$; Searchinger et al.'; Corn-ethanol: Liska et al. $^{8}$ (USA Midwest average); Farrell et al. ${ }^{9}$ (max.); Searchinger et al.' minus livestock savings (Table I); Gasoline: California, CARB, ${ }^{47}$ military emissions from Gulf oil (Table 2), line designates US avg.; Tar sands: Charpentier et al. ${ }^{61}$ WTR data were added to $89.2 \mathrm{gCO}_{2} \mathrm{e} \mathrm{MJ}^{-1}$ for emissions from refining and combustion; other fossil fuels: Brandt and Farrell, ${ }^{48}$ Estimated US gasoline GHG intensity in 2007 (97.7 $\mathrm{gCO}_{2} \mathrm{e} \mathrm{MJ}{ }^{-1}$ ) and 2020 (99.0 $\mathrm{gCO}_{2} \mathrm{e} \mathrm{MJ}^{-1}$ ) contain a tar sands fraction (Figure 2), assuming the average emission level, and California reformulated gasoline blendstock 47 ; 2020 value is the max. for gasoline.

of biofuels for petroleum be established to a greater degree of certainty, through additional modeling studies of indirect effects, case studies, and comprehensive evaluation.

\section{References}

I. Searchinger T, Heimlich R, Houghton RA, Dong F, Elobeid A, Fabiosa J, et al., Use of US croplands for biofuels increases greenhouse gases through emissions from land-use change. Science 3 1 9: 1238-1240 (2008).

2. US Congress, Energy Independence and Security Act (2007).

3. Kløverpris J, Wenzel H, Banse M, Canals ML, and Reenberg A, Conference and workshop on modeling global land use implications 
in the environmental assessment of biofuels. International Journal of Life Cycle Assessment 1 3: 178-183 (2008).

4. Meyers NJ and Raffensperger C, Precautionary tools for reshaping environmental policy. MIT Press, Cambridge, MA, (2006).

5. Allenby BR, Industrial ecology: Policy framework and implementation, Prentice Hall, Englewood Cliffs, NJ (1999).

6. Liska AJ and Cassman KG, Towards standardization of life-cycle metrics for biofuels: Greenhouse gas emissions mitigation and net energy yield. Journal of Biobased Materials and Bioenergy 2: I87-203 (2008).

7. National Research Council (NRC), Models in environmental regulatory decision making. National Academies Press, Washington DC, (2007).

8. Liska AJ, Yang HS, Bremer VR, Klopfenstein TJ, Walters DT, Erickson GE, and Cassman KG, Improvements in life cycle energy efficiency and greenhouse gas emissions of corn-ethanol. J Ind Ecol I3:58-74 (2009).

9. Farrell AE, Plevin RJ, Turner BT, Jones AD, O'Hare M, and Kammen $D M$, Ethanol can contribute to energy and environmental goals. Science 3 I I:506-508 (2006).

10. Canals LM, Bauer C, Depestele J, Dubreuil A, Knuchel RF, Gaillard G, et al., Key elements in a framework for land use impact assessment within LCA. International Journal of Life Cycle Assessment I2:5-I5 (2007).

II. Lifset R, Industrial ecology and public policy. J Ind Ecol 9:1-3 (2005).

12. Weidema BP, Thrane M, Christensen P, Schmidt J, and Løkke S, Carbon footprint: a catalyst for life cycle assessment? J Ind Ecol I 2:3-6 (2008).

13. IPCC, Climate change 2007: The physical science basis. Contribution of Working Group I to the Fourth Assessment Report of the Intergovernmental Panel on Climate Change. Cambridge University Press, New York (2007).

14. Lepers E, Lambin EF, Janetos AC, Defries R, Achard F, Ramankutty $\mathrm{N}$, and Scholes RJ, A synthesis of information on rapid land-cover change for the period 198I-2000. BioScience 55: I5-124 (2005).

15. Soares-Filho BS, Nepstad DC, Curran LM, Cerqueira GC, Garcia RA, Ramos CA, et al., Modeling conservation in the Amazon Basin. Nature 440:520-523 (2006).

16. Nepstad DC, Stickler CM, Soares-Filho B, and Merry F, Interactions among Amazon land use, forests and climate: Prospects for a near-term forest tipping point. Philos T Roy Soc B 363: 1727-1746 (2008).

17. Gullison RE, Frumhoff PC, Canadell JG, Field CB, Nepstad DC, Hayhoe K, et al., Tropical forests and climate policy. Science 3 16:985-986 (2007).

18. Turner BL, Lambin EF, and Reenberg A, The emergence of land change science for global environmental change and sustainability. Proc Natl Acad Sci USA 104:20666-2067I (2007).

19. Lambin EF and Geist HJ (eds.), Land-use and land-cover change: local processes and global impacts. Springer, Berlin (2006).

20. Geist HJ and Lambin EF, Proximate causes and underlying driving forces of tropical deforestation. Bioscience 52:143-150 (2002).

21. Naylor RL, Steinfeld H, Falcon W, Galloway J, Smil V, Bradford E, et al., Losing the links between livestock and land. Science 3 1 0: 162 I1622 (2005).

22. Hill J, Polasky S, Nelson E, Tilman D, Huo H, Ludwig L, et al., Climate change and health costs of air emissions from biofuels and gasoline. Proc Natl Acad Sci USA 1 06:2077-2082 (2009).

23. Fargione J, Hill J,Tilman D, Polasky S, and Hawthorne P, Land clearing and the biofuel carbon debt. Science 29:1235-1238 (2008).

24. Food and Agriculture Organization (FAO) of the United Nations. Forests and Energy - Key Issues, FAO Forestry Paper I54. FAO, Rome (2008).

25. Gibbs HK, Johnston M, Foley JA, Holloway T, Monfreda C, Ramankutty N, and Zaks D, Carbon payback times for crop-based biofuel expansion in the Tropics: The effects of changing yield and technology. Environmental Research Letters 3, 03400 I (2008).

26. Wahid MB, Weng CK, May CY and Chin CM, The need to reduce national greenhouse emissions: Oil palm industry's role. Journal of Oil Palm Research April Special Issue: I-23 (2006).

27. Nelson GC and Robertson RD, Green Gold or Green Wash: Environmental Consequences of Biofuels in the Developing World. Review of Agricultural Economics 30:5 I 7-529 (2008).

28. Kim H, Kim S and Dale BE, Biofuels, land use change, and greenhouse gas emissions: Some unexplored variables. Environ Sci Technol 43, 96I-96 (2009).

29. Delucchi M, A lifecycle emissions model (LEM): Lifecycle emissions from transportation fuels, motor vehicles, transportation modes, electricity use, heating and cooking fuels and materials. Institute of Transportation Studies UCD-ITS-RR-03-17, University of California, Davis (2003).

30. Hertel TW, Implications of US biofuels production for global land use. Presentation to the California Air Resources Board (2008).

31. Hertel TW, Rose S, and Tol R (eds.), Economic analysis of land use in global climate change policy. Routledge, London (in press).

32. Morton DC, DeFries RS, Shimabukuro YE, Anderson LO, Arai E, Espirito-Santo FD, et al., Cropland expansion changes deforestation dynamics in the southern Brazilian Amazon. Proc Natl Acad Sci USA 103:|4637-I464I (2006).

33. Naylor RL, Liska AJ, Burke MB, Falcon WP, Gaskell J, Rozelle SD, and Cassman KG, The ripple effect: biofuels, food security, and the environment. Environment 49:30-43 (2007).

34. Insitituto Nacional de Pesquisas Espacias (IPNE), Brazil. Projeto Prodes. Available at: http://www.obt.inpe.br/prodes/prodes 1988 2007.htm [January 2009].

35. Banse M, van Meijl H, Tabeau A and Woltjer G, Will EU biofuel policies affect global agricultural markets? Eur Rev Agric Econ 35:||7-|4| (2008).

36. Campbell JE, Lobell DB, Genova RC, and Field CB, The global potential of bioenergy on abandoned agriculture lands. Environ Sci Technol 42:579I-5794 (2008).

37. Lal R, Soil carbon sequestration impacts on global climate change and food security. Science 304:1623-1627 (2004). 
38. Millennium Ecosystem Assessment (MEA). Ecosystems and human wellbeing: Desertification synthesis. World Resources Institute, Washington, DC (2005).

39. Lal R, Potential of desertification control to sequester carbon and mitigate the greenhouse effect. Climate Change 5 I:35-72 (2001).

40. Near East and North Africa Regional Network for Agricultural Policies (NENARNAP), Report of the Technical Workshop on 'Expansion in biofuel and soaring food prices: implications for agricultural and food policies in the Near East and North Africa'. Cairo, Egypt (2008).

4I. Pan G, Li L,Wu L, and Zhang X, Storage and sequestration potential of topsoil organic carbon in China's paddy soils. Global Change Biology 1 0:79-92 (2003).

42. Li C, Qiu J, Frolking S, Xiao X, Salas W, Moore B, et al., Reduced methane emissions from large-scale changes in water management of China's rice paddies during 1980-2000. Geophys Res Lett 29, DOI: I0.1029/2002GLOI5370 (2002).

43. Danielsen F, Beukema H, Burgess ND, Parish F, Brühl CA, Donald PF, et al., Biofuel plantations on forested lands: double jeopardy for biodiversity and climate. Conserv Biol DOI: 10.1 III/j.15231739.2008.01096.x (2009).

44. Adviento-Borbe MAA., Haddix ML, Binder DL, Walters DT, and Dobermann A, Soil greenhouse gas fluxes and global warming potential in four high-yielding maize systems. Glob Change Biol I 3: 1972-1988 (2007).

45. Food and Agriculture Organization (FAO) of the United Nations. Livestock's Long Shadow. FAO, Rome (2006).

46. Rosenthal E, 'New jungles prompt a debate on saving primeval rain forests,' New York Times. January 30, 2009.

47. California Air Resources Board (CARB). Detailed CA-GREET pathway for California Reformulated Gasoline Blendstock for Oxygenate Blending (CARBOB) from average crude refined in California. Stationary Source Division. Version: 2.0, Release Date: January 12, 2009, Available at: http://www.arb.ca.gov/fuels/lcfs/ 011209lcfs_carbob.pdf [February 2009].

48. Brandt $A R$ and Farrell $A E$, Scraping the bottom of the barrel: greenhouse gas emission consequences of a transition to low-quality and synthetic petroleum Resources. Climate Change 84:24I-263 (2007).

49. O'Rourke D and Connolly S, Just oil? The distribution of environmental and social impacts of oil production and consumption. Annual Review of Environment and Resources 28:587-6I7 (2003).

50. Yetiv SA, Crude awakenings: global oil security and American foreign policy. Cornell University Press, Ithaca, NY (2004).

51. Horvath A, Construction materials and the environment. Annual Review of Environment and Resources 29:181-204 (2004).

52. Norgate TE, Jahanshahi S, and Rankin WJ, Assessing the environmental Impact of metal production processes. Journal of Cleaner Production 1 5:838-848 (2007).

53. Renner M, Environmental and health effects of weapons production, testing, and maintenance (Chapter 9), in War and Public Health, ed. by Levy BS and Sidel VW. Oxford University Press, New York (1997).
54. Copulos MR, The hidden costs of imported oil: An update. National Defense Council Foundation, Arlington,VA (2007).

55. Stiglitz JE and Bilmes LJ, The three trillion dollar war:The true cost of the Iraq conflict. W.W. Norton, New York (2008).

56. Rashid A, Taliban: Militant Islam, oil and fundamentalism in Central Asia. Yale University Press, New Haven, CT (2000).

57. International Energy Agency (IEA), World Energy Outlook 2008, IEA, Paris (2008).

58. Radler M, New estimates boost worldwide oil, gas reserves. Oil Gas J 106:20 (2008).

59. Burr JM and Collins RO, Alms for Jihad: Charity and terrorism in the Islamic world. Cambridge University Press, New York (2006).

60. Canadian Association of Petroleum Producers (CAPP), $2008 \mathrm{Ca}$ nadian Crude Oil Forecast and Market Outlook. Available at: http://membernet.capp.ca/default.asp?V_DOC_ID =1285 [January 2009].

6I. Charpentier AD, Bergerson JA and MacLean HL, Understanding the Canadian oil sands industry's greenhouse gas emissions. Environmental Research Letters 4:014005 (2009).

62. US Environmental Protection Agency (EPA). Inventory of US Greenhouse Gas Emissions and Sinks: 1990-2007 (Draft). Available at: http://www.epa.gov/climatechange/emissions/usinventoryreport. html [March 2009].

63. Schmer MR, Vogel KP, Mitchell RB and Perrin RK, Net energy of cellulosic ethanol from switchgrass. Proc Natl Acad Sci USA 105:464-469 (2008). Food and Agriculture Organization (FAO) of the United Nations. FAOSTAT database. http://faostat.fao.org/ site/377/default.aspx\#ancor [February 5, 2009]

Adam J. Liska is a Research Assistant Professor in the Department of Agronomy and Horticulture at the University of Nebraska-Lincoln. He completed a PhD in biology in 2003 at the Max Planck Institute of Molecular Cell Biology and Genetics, in Dresden, Germany, and a BSc in biochemistry and biology at the University of Nebraska-Lincoln.

Richard K. Perrin is the Jim Roberts Professor of Agricultural Economics at the University of Nebraska-Lincoln. He was Professor and Associate Head for Agricultural Economics at the Department of Economics \& Business at North Carolina State University and served for two years as economist at the International Maize and Wheat Improvement Center (CIMMYT) in Mexico.
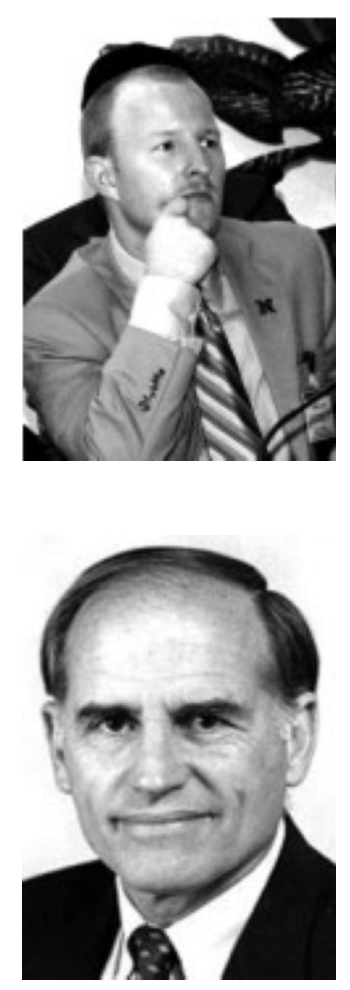